\title{
AUTOMATISASI PROCESSING EQUIPMENT DENGAN MENGGUNAKAN PLC PADA MESIN BUBUT KONVENSIONAL (BV - 20)
}

\author{
Dony Susandi, S.T., M.T. \\ Fakultas Teknik, Universitas Majalengka \\ ds777@ymail.com
}

\begin{abstract}
Dalam dunia industri, tidak terlepas dari adanya berbagai tuntutan, yaitu: pertama, menhasilkan produk dalam waktu yang singkat dengan biaya yang rendah dan berkualitas. Kedua, kemampuan mengubah variasi produk. Dan ketiga, sumber daya manusia. Sehingga memaksa para produsen untuk dapat tetap bertahan dan berkembang pada jalurnya, dan melakukan itu semua banyak metode perbaikan yang dapat dilakukan. Salah satu masalah utama dalam kegiatan penelitian ini adalah pemanfaatan teknologi otomasi (PLC) sehingga menghasilkan mesin yang memiliki tingkat perfomansi berbeda dengan mesin sebelumnya. Namun, sebelum melakukan itu seтиa, perlu difahami terlebih dahulu karakteristik operasional mesin baik itu mesin bubut itu sendiri maupun PLC-nya, sehingga dalam proses perancangan, pembuatan dan pengopera siannya akan lebih mudah dan mendapatkan hasil yang sesuai dengan yang diharapkan.
\end{abstract}

Keyword : PLC, Perancangan Konstruksi, Pengendalian Proses.

\section{PENDAHULUAN}

Teknologi otomasi merupakan pengembangan teknologi yang bersifat mekanik ( konvensional), dengan didukung perkembangan teknologi elektronik yang sangat pesat juga dipercepat dengan pengenalan IC dan Microprocessor. Perkembangan teknologi tidak terlepas dari adanya tuntutantuntutan, yaitu : pertama, menghasilkan produk dalam waktu yang singkat dengan biaya rendah dan berkualitas. Kedua, kemampuan mengubah variasi produk. Dan ketiga, sumber daya manusia. Agar dapat memenuhi tuntutan-tuntutan diatas, dalam menghasilkan suatu produk, dengan cara manual (konvensional) akan dibutuhkan seorang operator yang memiliki skill yang sangat tinggi dengan perlengkapan jig \& fixture yang kompleks.

Yang menjadikan otomasi penting dalam dunia industri adalah bahwa otomasi merupakan salah satu metode dan aspek penting dalam suatu rangkaian sistem manufaktur FMS (Flexibel Manufacturing System). Salah satu elemen teknologi otomasi yang dapat digunakan adalah dengan memanfaatkan Programmable Logic Control (PLC). Dibandingkan dengan teknologi otomasi yang lain $(\mathrm{NC}, \mathrm{CNC}$, DNC, dll), PLC memiliki beberapa keunggulan ; meningkatkan efesiensi kerja, keselamatan kerja, kons istensi tinggi dan mampu meningkatkan kualitas produk.

Dalam kegiatan penelitian ini, dititik beratkan pada pembahasan karakteristik operasional mesin bubut konvensional BV-20 dengan sistem kendali PLC. Agar tidak terjadi salah pengertian maka mesin dengan sistem kendali PLC dalam kegiatan penelitian ini disebut dengan Mesin bubut Otomatis.
Karakteristik dimaksud mencakup dua pengertian ; pertama ketelitian gerakan, terdiri dari dua elemen pengukuran yaitu ketepatan dan mampu ulang gerakan eretan atas maupun eretan bawah yang dinyatakan dalam satuan jarak. Yang kedua adalah waktu baku, yaitu sebagai ukuran performansi mesin otomatis yang dinyatakan dalam satuan waktu.

Dalam penelitian ini juga dilakukan evaluasi mesin bubut otomatis yang meliputi evaluasi perangkat lunak dengan memahami karakteristik operasional mesin ototmatis dikaitkan dengan aplikasinya pada pembuatan produk dalam membantu untuk menganalisis dan merancang sistem kendali otomatis tersebut.

Dengan kondisi tersebut, para produsen dituntut untuk dapat melakukan inovasi melalui penggunaan teknologi otomasi. Namun demikian, untuk melakukan itu semua, terlebih dahulu diperlukan pemahaman mengenai karakteristik operasional mesin otomatis dengan kendali PLC yang diinginkan sehingga performansi mesin tersebut dapat lebih optimal dalam pengoperasiannya

Berkaitan dengan hal diatas, maka penelitian ini diharapkan dapat memberikan sebuah evaluasi menyeluruh dari mulai perancangan, instalasi dan implementasi pemanfaatan teknologi PLC pada mesin bubut konvensional (BV-20).

\section{Landas an Teori Analisa Sistem Kontrol}

Analisa sistem kontrol, yaitu :

1. Hitung besarnya kecepatan roda gigi untuk tiaptiap motor : 
$n_{3}=\frac{N_{2}}{N_{3}} n_{2}=\frac{d_{2}}{d_{3}} n_{2}$

Dimana $n=$ rpm atau jumlah putaran

$$
N=\text { jumlah gigi }
$$

$d=$ diameter puncak

2. Tentukan besarnya jarak-maju/mundur leadscrew per ulir dan besarnya sudutmaju ulir :

- Jarak-maju leadscrew per ulir, yaitu :

$l=n . p$,

denganfaktor keamanan( $n)$ dan menpakan harga praktris

AGMA untuk sekerup/ulir dimana $n \geq 2$

- Sudut maju ulir, yaitu :

$$
\tan \lambda=\frac{l}{\pi d_{m}}
$$

3. Hitung besarnya daya putar motor :

$$
T=\frac{63000 H}{n}
$$

4. Tentukan kemampuan self-locking ( kondisi untuk mengunci sendiri ), yaitu :

$\mu \geq \tan \lambda$,

dimana besarnya koefesien gesek ulir adalah

$$
\mu=\frac{l}{\pi d_{m}},
$$

5. Hitung besarnya daya untuk menaikkan/menurunkan beban:

- Torsi untuk menaikkan/menurunkan beban tanpa penahan, yaitu :

$T=\frac{F \cdot d_{m}}{2}\left(\frac{l+\pi \cdot \mu \cdot d_{m} \cdot \sec \alpha}{\pi \cdot d_{m}-\mu \cdot l \cdot \sec \alpha}\right)$

- Torsi untuk menaikkan/menurunkan beban dengan penahan, yaitu :

$T=\frac{F \cdot \mu \cdot d_{c}}{2}$

6. Menghitung besarnya kecepatan jarakmaju/mundur eretan dari putaran poros yang bergerak, yaitu :

$$
\frac{F V}{33000}=\frac{T n}{63000}
$$

\section{Evaluasi Sistem Kontrol}

\section{a) Pengendalian Waktu Proses}

Tahap ini merupakan penentuan standar waktu operasi jarak-maju/mundur eretan pada masingmasing motor penggerak serta menentukan batas toleransi wilayah kerja mesin otomatis hasil perancangan-pembuatan berdasarkan hasil pengujian sebelumnya. Untuk menentukan jarak-maju/mundur eretan per satuan waktu menggunakan persamaan berikut :

1. Hitung besarnya rata-rata dan deviasi standarnya dengan menggunakan persamaan berikut, untuk tiap-tiap arah gerak motor :

$\bar{x}=\frac{\sum_{i-1}^{n} x_{i}}{n}$

dengan deviasi standar sebagai berikut :

$$
\begin{aligned}
& S=\sqrt{\frac{\sum_{i=1}^{n}\left(x_{i}-\bar{x}\right)^{2}}{n-1}} \\
& \text { dimana } \quad x_{i}=\text { jumlah sampel pengukuran } \\
& n=\text { ukuransampel }
\end{aligned}
$$

2. Tentukan batas toleransi dengan tingkat kepercayaan tertentu menggunakan persamaan berikut :

Batas toleransi dapat ditentukan dengan : $\bar{x} \pm k . s$, maka nilai dari batas toleransi itu sendiri adalah :

Tol $= \pm k . s$

dimana,

$\mathrm{k}=$ diperoleh dari tabel 1 lampiran $\mathrm{C}, 1-\alpha$ merupakan tingkat kepercayaan data pengukuran dan $\gamma$ adalah besarnya batas toleransi yang diinginkan.

3. Buat peta kendali untuk nilai-nilai diatas.

\section{b) Ketepatan}

Ketepatan adalah perbedaan antara posisi yang diinginkan dengan yang dicapai. Metodologi pengukuran ketepatan adalah mula-mula ditentukan posisi tujuan yang berada dalam ruang kerjanya, kemudian elemen gerak makan dalam hal ini adalah eretan diarahkan ke posisi tersebut sebanyak $n$ kali. Besarnya posisi yang dicapai yang dilakukan sebanyak $n$ kali dicatat sebagai data pengukuran.

Langkah-langkah pengukuran selengkapnya :

1. Data hasil pengukuran

2. Hitung besarnya rata-rata dan deviasi standarnya dengan menggunakan persamaan berikut, untuk tiap-tiap motor :

Titik acuan $\quad x i \quad$ Titik tujuan $\quad X^{\prime}$

$$
\bar{x}=\frac{\sum_{i-1}^{n} \sqrt{\left(x_{t}-x_{i}\right)^{2}}}{n}
$$

jarak titik yang dicapai dengan tujuan, yaitu :

$$
\begin{aligned}
& d_{i}=\sqrt{\left(x_{t}-x_{i}\right)^{2}} \\
& s=\sqrt{\frac{\sum_{i=1}^{n}\left(\bar{x}-d_{i}\right)^{2}}{n-1}}
\end{aligned}
$$


Buat batas kelas dan distribusi frekuensi untuk masing-masing motor .

3. Hitung nilai $\mathrm{Z}$ untuk setiap batas kelas interval dengan rumus :

$$
\begin{aligned}
& z_{1}=\frac{x i-\bar{x}}{s} \text { dan } z_{2}=\frac{x i-\bar{x}}{s} \\
& \text { dimana, } \\
& x_{i}=\text { Batas kelas interval ke }-\mathrm{i} \\
& \bar{x}=\text { Rata }- \text { rata pada persamaan } 3.11 \\
& \mathrm{~s}=\text { standardeviasipada persamaan } 3.13
\end{aligned}
$$

4. Tentukan luas daerah dibawah kurva normal untuk setiap kelas intrval dari tabel normal standar ( tabel 4 lamp. C ).

5. Hitung frekuensi yang diharapkan dengan persamaan :

$e_{i}=n . P(k)_{t}$

6. Uji kenormalan dilakukan dengan goodness of fit pada tingkat kepercayaan tertentu, dengan menggunakan persamaan :

$$
\begin{aligned}
& x^{2}=\sum_{i=1}^{k} \frac{\left(o_{i}-e_{i}\right)^{2}}{e_{i}} \\
& \text { dimana } \quad k=\text { BanyaknyaKelas } \\
& o_{i}=\text { Nilai observasi kelas ke }-\mathrm{i} \\
& e_{i}=\text { Nilai Ekspetasikelas ke }-\mathrm{i}
\end{aligned}
$$

dengan kriteria pengujian adalah : tolak hipotesis kenormalan jika $x^{2} \geq x^{2}{ }_{(1-\alpha)(k-1)}$ dengan $\alpha=95 \%$ menyatakan tingkat kepercayaan pengujian.

\section{c) Mampu Ulang}

Pengukuran mampu ulang dapat dilakukan seiring dengan pengukuran ketepatan. Pengukuran mampu ulang merupakan pengukuran terhadap kemampuan untuk kembali ke posisi awal ( home position ).

Dari data yang diperoleh pada pengukuran ketepatan, besarnya mampu ulang untuk masingmasing motor ditentukan dengan langkah sebagai berikut :

1. Tentukan nilai rata-rata mampu ulang dengan menggunakan persamaan berikut :

$$
\bar{y}=\frac{\sum_{i=1}^{n} \sqrt{\left(x_{i}-\bar{x}\right)^{2}}}{n}
$$

dimana,

$\bar{y}=$ rata-rata mampu ulang

$\overline{\mathrm{X}}=$ rata-rata ketepatan pada persamaan 3.14

dengan standar deviasi : $\mathrm{s}_{\mathrm{y}}=\sqrt{\frac{\sum_{\mathrm{i}=1}^{\mathrm{n}}\left(\overline{\mathrm{y}}-\mathrm{dy}_{\mathrm{i}}\right)^{2}}{\mathrm{n}-1}}$

$d y_{j}$ meny atakanjarak y ang dicapai dengan rata- rata:

$d y_{i}=\sqrt{\left(x_{i}-\bar{x}\right)^{2}}$

\section{Simulasi Model Fisik}

Tahap simulasi model fis ik adalah tahap penentuan performansi waktu proses mesin konvensional dengan mesin otomatis. Agar lebih mudah pengukuran perbandingannya, kedua mesin dioperasikan dengan menggunakan material yang sama dan variasi produk yang sama. Sebagai berikut adalah langkah-langkah dalam melakukan proses pengukuran performansi untuk masing-masing mesin yaitu :

1. Tentukan kerangka sistem yang dimodelkan dan rancangan produk sistem.

2. Catat waktu operasi langkah pertama dan hitung waktu rata-rata serta penyimpangannya dengan menggunakan persamaan.

3. Buat tabel waktu operasi mesin konvensional dengan mesin otomatis.

4. Tentukan hipotesis pengujian tolak Ho jika $t_{h}>$ $t_{\text {tabel }}$ dengan kebebasan $\mathrm{v}=\mathrm{k}-2$ pada taraf kepercayaan $\alpha=95 \%$; jika sebaliknya terima Ho.

5. Hitunglah nilai $t_{h}$ sebagai pengujian hipotesis dengan menggunakan persamaan berikut :

$$
\begin{gathered}
t_{h}=\frac{\left(\bar{x}_{1}-\bar{x}_{2}\right)-d_{o}}{S_{P} \sqrt{\left(1 / n_{1}\right)+\left(1 / n_{1}\right)}} \\
\text { a } S_{p}=\frac{\left(n_{1}-1\right) S_{1}^{2}+\left(n_{2}-1\right) S_{2}^{2}}{n_{1}-n_{2}-2}
\end{gathered}
$$

6. Tentukan kesimpulan berdasarkan nilai $t_{h}$ dengan $t_{\text {tabel }}$

Sebagai langkah terakhir dari pengukuran performansi adalah pengukuran variansi performansi. Sebagai berikut adalah langkahlangkah tersebut :

5. Langkah 1-4 adalah sama dengan langkah pada pengukuran performansi.

6. Tentukan hipotesis pengujian tolak Ho jika $F_{h}>$ $F_{\alpha}$ dengan derajat kebebasan $\mathrm{v}_{\mathrm{m}}=\mathrm{n}_{\mathrm{n}}-1$ dan $\mathrm{v}_{\mathrm{n}}=$ $\mathrm{n}_{\mathrm{m}}-1$ pada taraf kepercayaan $\alpha=95 \%$; jika sebaliknya terima Ho.

7. Hitunglah nilai $F_{h}$ sebagai pengujian hipotesis dengan menggunakan persamaan berikut :

$$
F_{h}=\frac{S_{1}^{2}}{S_{2}^{2}}
$$

8. Tentukan kesimpulan berdasarkan nilai $t_{h}$ dengan $t_{\text {tabel }}$. 


\section{Sinkronisasi Fungsi Waktu}

Sinkronisasi fungsi waktu pada PLC dengan jarak yang dihasilkan oleh kedua eretan. Mula-mula tentukan posisi tujuan (t waktu tempuh PLC/timer) yang berada dalam ruang kerjanya, kemudian eretan diarahkan ke posisi tersebut sebanyak $\mathrm{n}$ kali, besarnya posisi yang dicapai dalam tersebut dicatat sebagai data pengukuran.

Sebagai berikut adalah langkah-langkah dalam melakukan pengukuran, yaitu :

Langkah-langkah pengukuran selengkapnya :

1. Tentukan titik tujuan yang berada dalam ruang kerjanya, misal Xt :

2. Arahkan eretan ke posisi yang dituju, lakukan sebanyak $n$ kali. Catat posisi atau simpangannya untuk masing-masing koordinat yang dicapai.

3. Lakukan pengujian kecukupan data, untuk tingkat kepercayaan tertentu dan tingkat ketelitian tertentu, sebagai contoh tingkat kepercayaan $95 \%$ dan tingkat ketelitian $5 \%$ digunakan persamaan :

$$
N^{\prime}=\left[\frac{40 \sqrt{N \sum_{i=1}^{n} X_{i}^{2}-\left(\sum_{i=1}^{n} X_{i}\right)^{2}}}{\sum_{i=1}^{n} X_{i}}\right] \text {..persamaan } 3.10
$$

Jika $\mathrm{N}^{\prime}<\mathrm{N}$ maka data pengukuran dinyatakan cukup.

\section{Metodologi Penelitian}

Penelitian ini terdiri dari dua tahap utama, yaitu : tahaa pertama adalah perancangan, pembuatan dan pengoperasian sistem kontrol, tahap kedua adalah evaluasi hasil pengoperasian sistem kontrol.

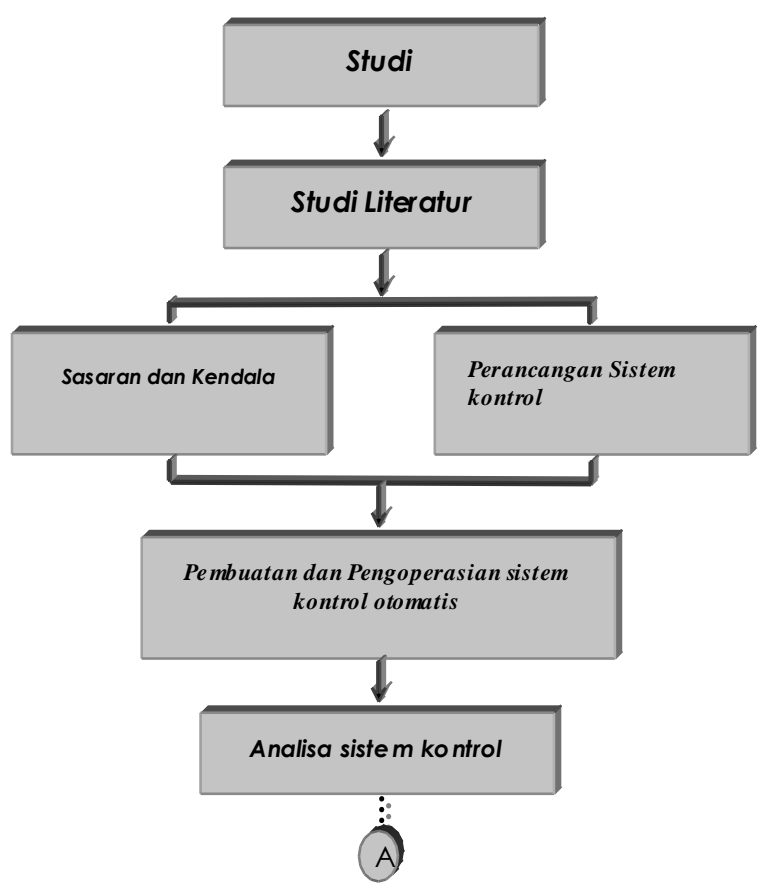

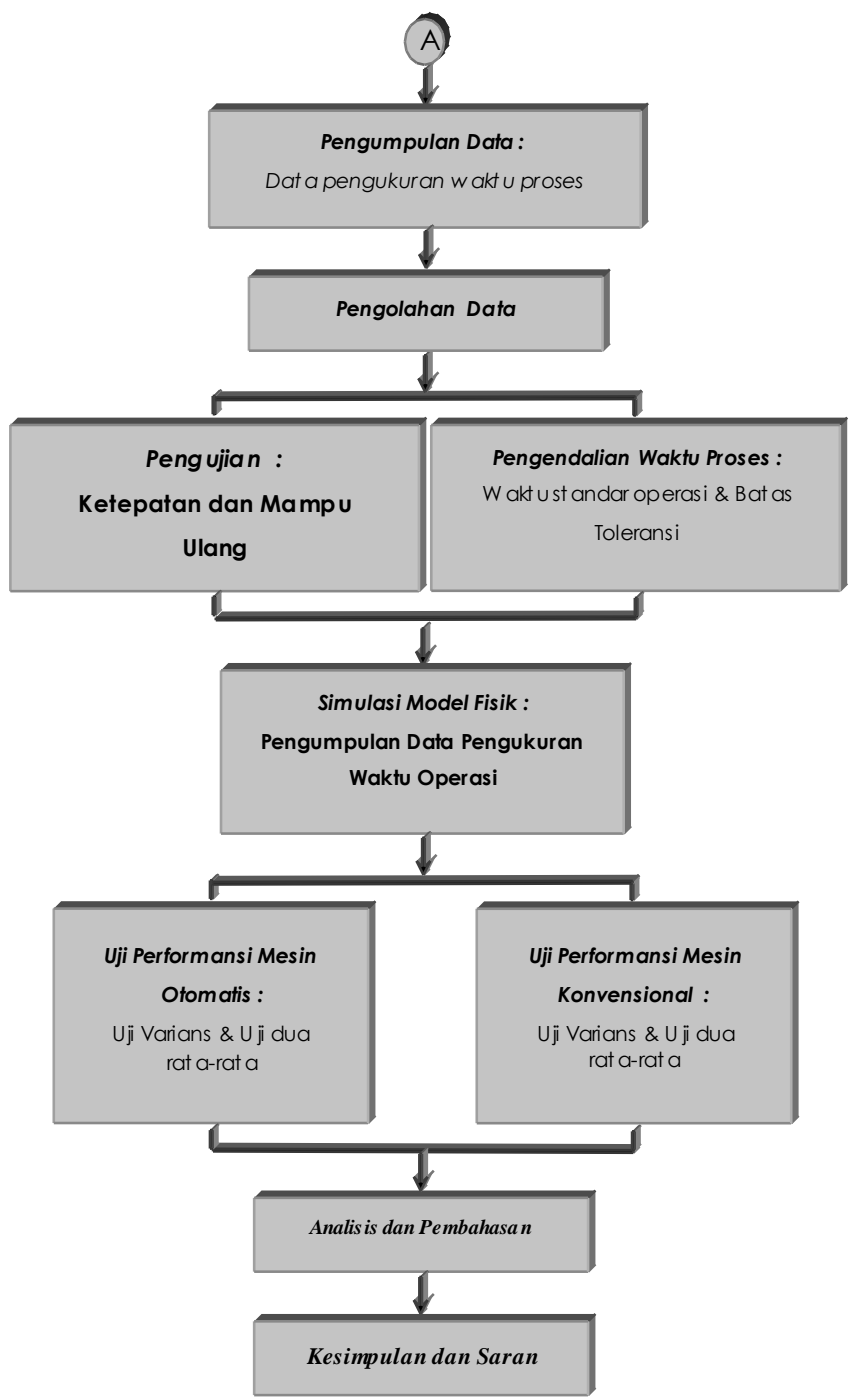

Gambar 2. Kerangka Pemecahan Masalah

\section{1) Pendekatan Perancangan}

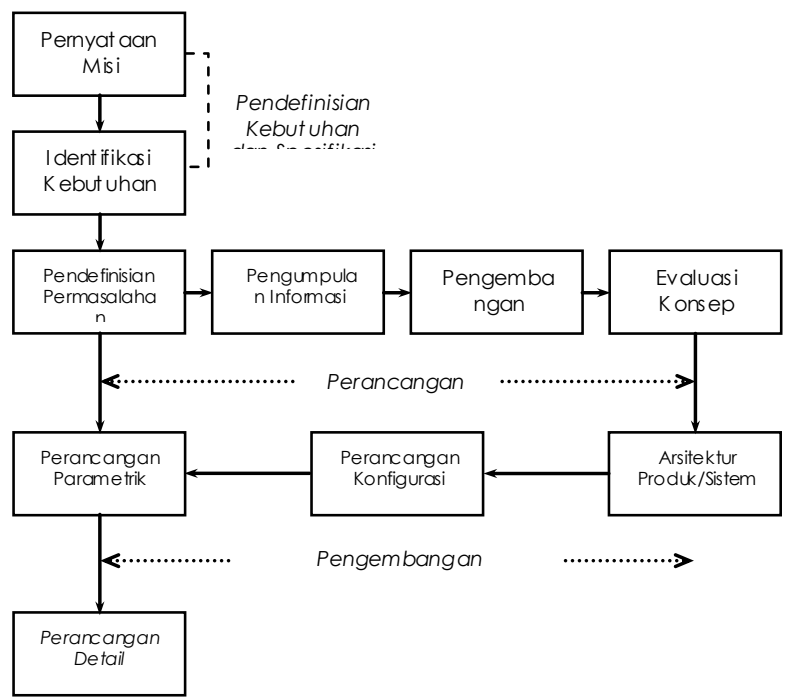

Gambar 3. Pola Pendekatan Perancan gan 
a) Pendefinisian Kebutuhan dan Spesifikasi

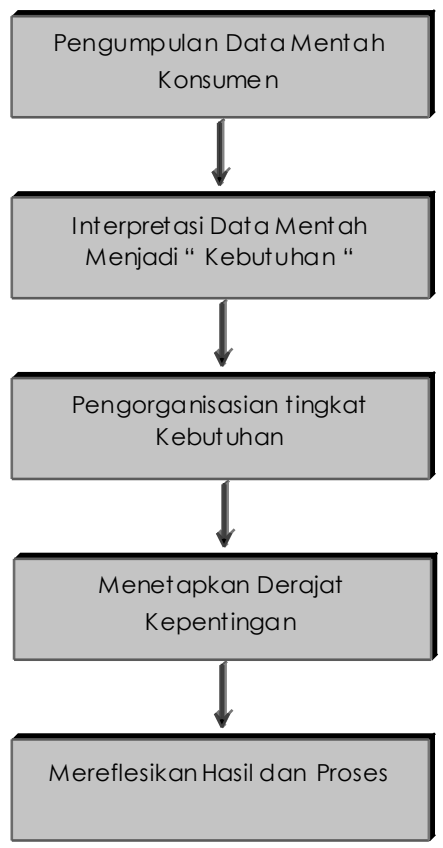

Gambar 4. Pendefin isian Kebutuhan dan Spesifikasi

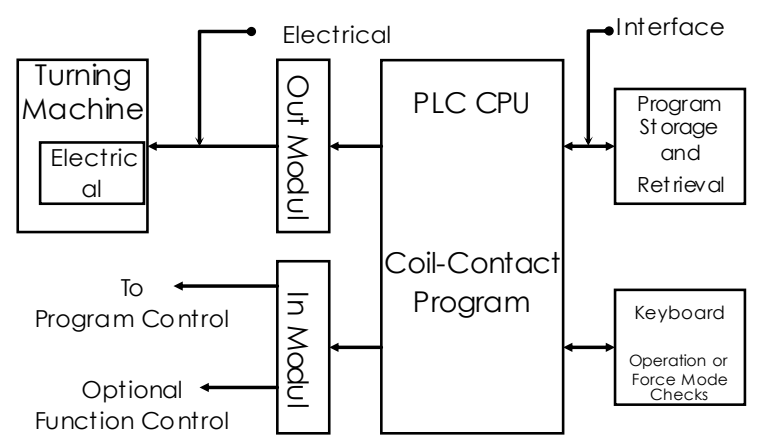

Gambar 5. Block Diagram Sistem Kontrol PLC Mesin Bubut BV-20

b) Perancangan Konseptual (Pemilihan Teknologi)

- Teknologi Komputer

- Programmable Controller

- Processing Equipment

c) Perancangan Parametrik (Spesifikasi

Rancangan)

Hasil dari proses perancangan konseptual yaitu berupa spesifikasi rancangan yang menjadi titik tolak dalam pembuatan Sistem Kontrol automatis, yaitu sebagai berikut :

- Personal Computer

- Programmable Logic Controller

- Processing Equipment

\section{2) Penge mbangan Model Simulasi Fisik}

a. Elemen-elemen Sistem Operasi yang Dimodelkan Sistem yang akan dimodelkan terdiri atas elemen-elemen sebagai berikut :
a) PLCs
b) Limit Swtich
c) Produk yang akan diproses
d) Mesin bubut BV-20
e) Pengendali computer

b. Deskripsi Sistem yang Dimodelkan

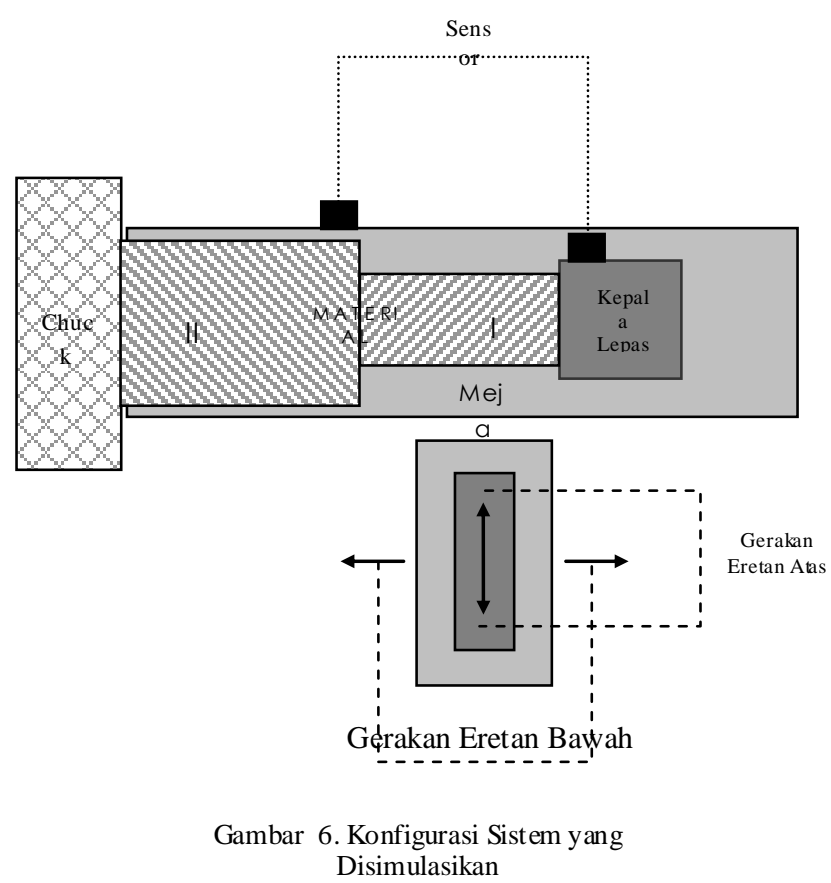

IV. Perancangan dan Analisa

4.1 Gambaran Umu m dan Data Spesifikasi Mesin Bubut B V-20 Konvens ional.

Sebagai berikut adalah data spesifikasi secara umum dari mesin bubut BV-20 konvensional, yaitu

1. Source Voltage

2. Drives

3. Maks Dia Spindel

4. Center Length

5. Change Gear

6. Carrier Bottom-Carrier

7. Operation Turning

Mesin bubut adalah mesin perkakas dengan gerak utama berputar. Mesin bubut dapat dioperasikan untuk membuat bentuk-bentuk silindris, akan tetapi dapat digunakan juga untuk yang lain, bisa dilengkapi mekanisme lain yang dapat digunakan untuk mengerjakan operasi lain sebagai tambahan fungsi-fungsi dasarnya.

Sebagai berikut adalah bagian-bagian utama dari mesin bubut beserta fungsinya :

a. Kepala tetap 
b. Kepala lepas

c. Meja mesin / bed

d. Eretan

e. Kelengkapan alih gerak laju

Dalam membubut suatu bahan diperlukan beberapa gerakan, yaitu :

a. Gerakan berputar

b. Gerakan memanjang

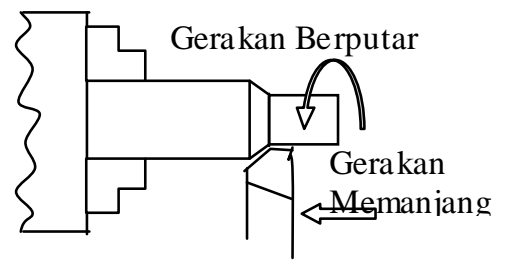

Gambar 7. Gerakan Memanjang

c. Gerakan Melintang

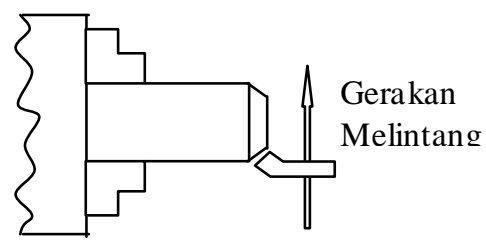

Gambar 8. Gerakan Melintang

\subsection{Penge mbangan model fisik}

Dibawah ini adalah masing-masing pengembangan model fisik dari sistem kontrol otomatis yang dilakukan berdasarkan pada proses perancangannya.

$>$ Teknologi komputer

Pada tahap ini tidak ada proses pembuatan secara khusus dari teknologi komputer. Seperti telah dijelaskan sebelumnya, bahwa teknologi hanya dimanfaatkan sebagai media pembuat program dan transfer program serta Online Monitoring process.

> Programmable Logic Control

Pada dasarnya PLC merupakan interface dari teknologi komputer dengan processing equipment, Untuk itu, maka penulis mamanfaatkan salah satu fungsi dari PLC yaitu sebagai pengendali logika untuk coilcontact/sakelar magnetik atau sering disebut dengan kontaktor (Relay). PLC tersedia di pasaran dengan berbagai jenis merek dalam bentuk software dan hardware dengan jenis dan fungsi yang berbeda-beda.

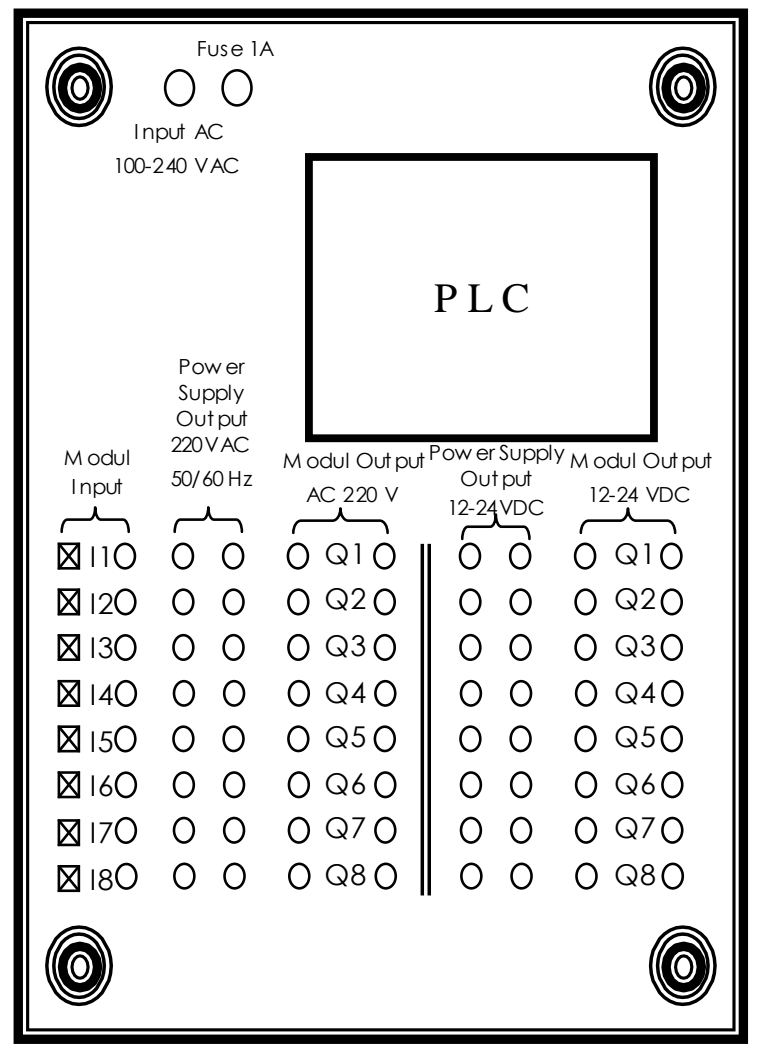

Gambar 10. Rangka Khusus PLC

\section{Processing Equipment}

Mesin bubut BV-20 yang digunakan pada kegiatan penelitian berlangsung terdiri dari struktur mekanis dan elektronik. Seperti telah dinyatakan sebelumnya, tidak ada perubahan mendasar pada konstruksi dasar mesin tersebut. Akan tetapi, dilakukan modifikasi pada poros penghubung untuk pergerakan eretan bawah dimana sebelumnya secara otomatis digerakkan oleh gearbox spindle. setelah modifikasi, poros sistem gearbox tidak dihubungkan lagi tetapi menggunakan motor penggerak tersendiri.

Selain itu, modifikasi dilakukan pada poros eretan atas, sebelum perancangan, penggerak eretan atas dilakukan secara manual (mesin bubut BV-20 konvensional) dengan menggunakan handle putar. Sistem geraknya adalah dengan memutar handle tersebut sehingga menghasilkan gaya yang menggeserkan rel eretan atas, dengan demikian, rumah pahat akan turut bergerak (maju/mundur) dengan bergesernya rel tersebut. Dengan modifikasi, handle eretan tersebut kemudian dilepas/tidak digunakan lagi dan diganti dengan menggunakan sebuah motor penggerak, untuk lebih jelas lihat struktur mekanik motor penggerak.

Mesin bubut BV-20 memiliki struktur mekanik yang sederhana dibandingkan dengan mesin bubut 
lain yang lebih besar dengan kemampuan operasi yang lebih baik. Pada proses perancangan konseptual, telah disebutkan sebagai nilai output untuk PLC maka digunakan tiga buah motor penggerak yang menghasilkan gerakan untuk masing-masing poros gerak bagian utama mesin tersebut.

\subsection{Struktur Mekanik Penggerak Spindel}

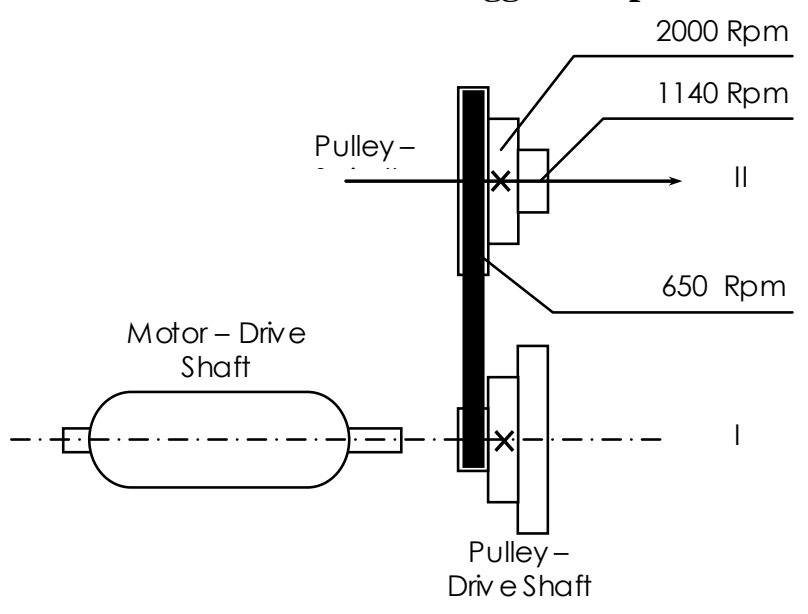

Gambar 11. Sistem pulley bertingkat kecepatan tingkat tinggi

Sebagai motor penggerak pada struktur mekanik spindel adalah motor 1 phase, dengan tegangan 220 Vac, 50/60 Hz dengan kecepatan putaran maksimum sebesar $1450 \mathrm{rpm}$. Pada gambar 11 menunjukkan struktur mekanik motor penggerak spindel, dimana struktur tersebut terletak pada head stock/kepala tetap. Salah satu fungsi dari head stock seperti dije laskan pada landasan teori ada lah sebagai rumah pe-ubah kecepatan putaran spindel. Sistem pe-ubah kecepatan spindel mesin bubut BV-20 yang digunakan dan merupakan kondisi standar pada mesin tersebut yaitu menggunakan sistem pulley bertingkat, pada setiap tingkatan pulley akan menghasilkan besaran maksimum putaran spindel yang berbeda-beda. Untuk mengendalikan pulleypulley tersebut, maka digunakan belt (sabuk/tali penghubung). Belt tersebut terbuat dari berbagai macam bahan diantaranya benang kasar, plastik dan bahan-bahan campuran lainnya. Namun, pada umumnya dan banyak tersebar di pasaran adalah yang terbuat dari karet karena selain kualitasnya cukup lumayan juga harganya murah dibandingkan dengan bahan-bahan belt lainnya. Dengan berbantuan dua pulley tersebut akan menghasilkan putaran maksimum spindel pada putaran tingkat tinggi. Hal tersebut terjadi karena, pulley-drive shaft dihubungkan langsung pada pulley spindel. Artinya, kecepatan putaran motor penggerak tidak direduksi dengan menggunakan intermidiate pulley.
Dengan menggunakan intermidiatte pulley, yang berfungsi sebagai penyearah putaran dan pe-reduksi kecepatan maka dapat dihasilkan motor dengan kecepatan putaran maksimum spindel pada putaran tingkat rendah. Struktur mekanik pulley tersebut dapat dilihat pada gambar 11, dimana menggunakan tiga buah pulley, yaitu : a. pulley drive shaft ( I ), b. intermidiatte pulley ( II ) dan c. pulley spindel ( III ) .

\subsection{Struktur Mekanik Pengge rak Eretan Bawah}

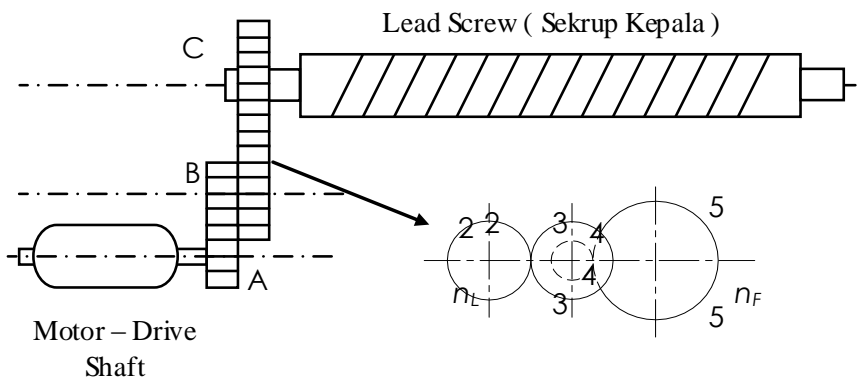

Gambar 12. Mekanisme Roda Gigi Penggerak Eretan Bawah

Motor penggerak eretan bawah memiliki kecepatan maksimum $1200 \mathrm{rpm}$, dengan tegangan input sebesar $220 \mathrm{VAC} 50 / 60 \mathrm{~Hz}$ dan daya output adalah $1 / 2$ hp. Motor tersebut digunakan untuk memutar lead screw penggerak eretan bawah. Pada tahap ini, sebelumnya te lah digunakan motor dengan berbagai kecepatan dan daya yang berbeda-beda. Seiring dengan pemilihan dan pembuatan untuk penggerak eretan bawah, ditemukan berbagai macam kendala dalam menentukan motor yang akan digunakan seperti, motor harus memiliki kecepatan rendah tetapi memiliki daya yang mampu mengangkat beban yang dimiliki oleh eretan tersebut serta mampu menghasilkan perpindahan gerak eretan (satuan jarak $=\mathrm{mm}$ ) yang sangat kecil.

Motor yang digunakan adalah motor dengan sistem roda gigi (gear box) dengan perbandingan 1 : 30, dengan menggunakan rumus (Persamaan 3.1) maka kecepatan maksimum motor dengan roda gigi menjadi $40 \mathrm{rpm}$. Kecepatan putaran maksimum tersebut setelah dihubungkan dengan sumbu leadscrew eretan tanpa beban (tanpa handel otomatis) cukup besar, dan setelah di terapkan pada mekanisme penggerak eretan bawah dengan beban (menggunakan handel otomatis eretan), motor tersebut mampu mengangkat beban yang dimiliki oleh eretan bawah tersebut. Akan tetapi, kecepatan gerak (jarak-maju/mundur) yang dihasilkan eretan bawah masih terlalu besar, sehingga masih perlu dilakukan pe-reduksian putaran yang dapat menghasilkan kecepatan garis puncak $(V)$ sehingga jarak-maju-mundur $(l)$ eretan kurang lebih $1 \mathrm{~mm} /$ det. 
Hasil dari proses pembubutan pemotongan logam oleh pahat sangat ditentukan oleh kecepatan arah gerak eretan bawah. Fungsi utama dari sistem mekanik eretan bawah adalah perpindahan ulir leadscrew per gang, dimana akan menentukan hasil pembubutan dengan permukaan material yang rata disebut dengan membubut muka rata dan hasil pembubutan yang memiliki permukaan dan lembah atau sering disebut dengan membubut ulir. Sedangkan untuk mengatur kecepatan perpindahan gerak eretan bawah, penulis mencoba mengadopsi dan menerapkan mekanisme roda gigi yang paling sederhana yang disebut dengan Rangkaian Roda Gigi Reduksi Ganda, dimana efek yang tidak biasa didapat dalam rangkaian roda gigi dengan memperkenankan beberapa sumbu roda gigi berputar terhadap sumbu roda gigi yang lain.

\subsection{Struktur Mekanik Pengge rak e retan atas}

Motor - Drive Shaft yang digunakan harus memiliki spesifikasi khusus, karena kecepatan putaran maksimum motor harus rendah dan memiliki torsi yang besar untuk membawa rumah pahat serta beban pemakanan dari pahat yang diumpankan terhadap material. Motor tersebut dipasang pada tegangan $220 \mathrm{VAC} 50 / 60 \mathrm{~Hz}$ yang memiliki putaran maksimum $900 \mathbf{~ r p m}$ dengan daya $(\mathrm{H})=1 \mathrm{hp}$ dan sistem roda gigi dengan perbandingan 1 : 30, artinya putaran maksimum yang dihasilkan adalah $30 \mathrm{rpm}$ pada sistem roda gigi dan $900 \mathrm{rpm}$ pada putaran magnet motor tersebut.

\section{$>$ Power Sistem (Struktur Elek tronik)}

Sistem kontrol otomatis yang dibuat menggunakan tenaga listrik sebagai tegangan input, pada spesifikasi rancangan ditentukan sumber tegangan yang digunakan adalah tenaga listrik tegangan tinggi $220 \mathrm{VAC} 50 / 60 \mathrm{~Hz}$. Terdapat dua terminal tegangan input yaitu, untuk terminal PLC dan terminal electric control box (processing equipment).

Pada terminal PLC, sumber tegangn input adalah $220 \mathrm{VAC}$, sebagai pengaman arus, maka digunakan sikering pengaman sebesar $1 \mathrm{~A}$ (quick blow). Pada electric controlbox processing equipment, penghubungan rangkaian lingkaran arus atau rangkaian tetap dilakukan langsung dengan jaringan distribusi tegangan, cara ini sederhana, murah dan memberi kopel asut yang baik. Jika arus asutnya tinggi tidak menimbulkan gangguan bagi jaringan suplai dan kejutan mekanis yang disebabkan oleh gaya-gaya percepatan yang timbul, juga tidak menimbulkan gangguan bagi mesin yang digerakkan. Penghubungan ini dilakukan dengan menggunakan sakelar yang dilayani secara elektromagnetik (saklar magnet atau kontaktor), dimana motor dapat dilayani dari jauh dan secara otomatis. Untuk menghasilkan arah gerakan yang berbeda-beda, maka dilakukan pembalikan arah putaran untuk setiap motornya kecuali motor penggerak spindel.

\section{$>$ Program Pengendali}

Bagian terpenting dari sistem kontrol otomatis adalah controlling (pengendalian) itu sendiri, dimana secara kelistrikan PLC memiliki keutamaan dalam pengendalian alat-alat industri (timer, saklar dan lain-lain). Pada program pengendali PLC memiliki program internal sebagai pengganti alatalat industri tersebut, sehingga tidak memerlukan alat-alat iindustri tambahan yang membutuhkan investasi besar dalam melakukannya. PLC pada kegiatan perancangan yang dilakukan adalah digunakan untuk pengendalian dan pengaturan coilcontact (kontaktor/saklar magnetik) pada box kontrol kelistrikan processing equipment hasil perancangan. Dengan berbantuan program pengendali pada kontrol komputer (komputerisasi), kontaktor yang dihubungkan dengan masing-masing motor penggerak yang menghasilkan arah putaran dan gerak eretan pada fungsinya masing-masing dalam setiap proses pembubutan menjadi input program pengendali.

Dalam hal ini, program yang digunakan adalah Zelio Soft Ver 1.5. Komponen input/output processing equipment, Dimensi (bentuk, ukuran, jenis bahan dan lain-lain) material menjadi variablevariabel yang sangat penting dan saling berhubungan sehingga sistem kontrol otomatis mesin bubut BV-20 dapat berfungsi dengan baik. Setiap komponen input PLC dapat berfungsi sebagai pengontrol dari sistem kontrol otomatis tersebut. Sehingga tidak keluar dari arah dan gerak yang telah ditetapkan oleh program pengendali pada kontrol komputer. Program pengendali pada mesin bubut pada dasarnya adalah digunakan untuk mengidentifikasi arah gerakan elemen pembubut ( eretan atas dan atau eretan bawah ) sehingga dapat menghasilkan suatu bentuk material hasil proses pembubutan.

\section{Communication}

Seperti yang telah dibahas pada bagian perancangan, penugasan sistem kontrol otomatis dilakukan oleh teknologi komputer, walaupun PLC pada perkembangan sekarang ini banyak PLC yang dilengkapi dengan membran keypad dan LCD dengan berbagai ukuran yang dapat mem-program suatu perintah penugasan tanpa membutuhkan teknologi komputer secara terpisah.

Untuk itu, diperlukan jalur komunikasi antara teknologi komputer dengan processing equipment. Ini dilakukan dengan memanfaatkan sarana komunikasi yang telah ada pada controller PLC, 
yaitu port komunikasi serial COM1 atau COM2 dengan menggunakan interface RS-232.

Sedangkan jalur komunikasi dari PLC dengan processing equipment dan jalur komunikasi aliran daya hanya menggunakan kabel standar kelistrikan yang memiliki kekuatan untuk mengalirkan arus listrik pada tegangan yang konstan. Hal itu dilakukan dengan memanfaatkan kabel berserabut yaitu NYAF 0.75 yang berjumlah 24 yang memiliki kemampuan dialiri arus listrik maksimum 5,5 A dengan tegangan maksimum 450/750 Volt.

\subsection{Logika Pemograman Kontrol Sis tem}

Pemograman dilakukan dengan menjabarkan fungsi-fungsi kontrol kedalam bentuk logika pemograman.

\subsubsection{Logika pemograman kontrol computer}

Diagram alir dari kontrol komputer dapat dilihat pada gambar 13, Diagram alir tersebut menggambarkan fungsi-fungsi dari kontrol komputer, dimana fungsi dari kontrol komputer adalah fungsi yang mengendalikan sistem secara keseluruhan berdasarkan status terakhir dari sistem.

Pada diagram alir tersebut terdapat fungsi-fungsi kontrol, yang dapat menentukan aliran utama sistem secara keseluruhan, yaitu :

口 Fungsi pemantauan dan pengendalian sistem operasi keseluruhan

a Fungsi pengiriman status perintah

a Fungsi pengendali gerak processing equipment

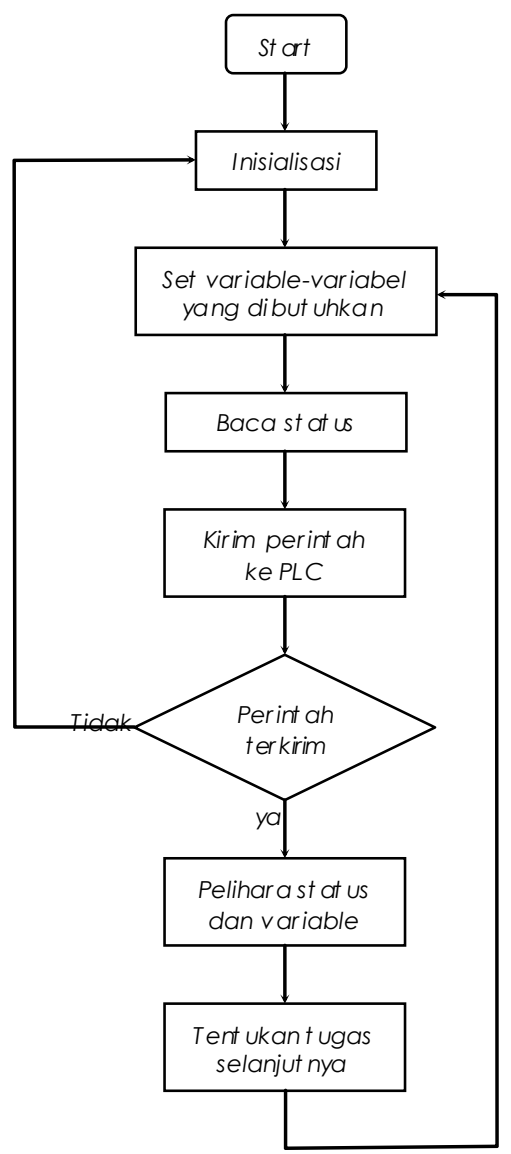

\subsubsection{Logika pemograman kontrol PLC}

Diagram alir dari kontrol PLC dapat dilihat pada gambar 14 diagram alir tersebut mengambarkan fungsi-fungsi dasar dari kontrol PLC.

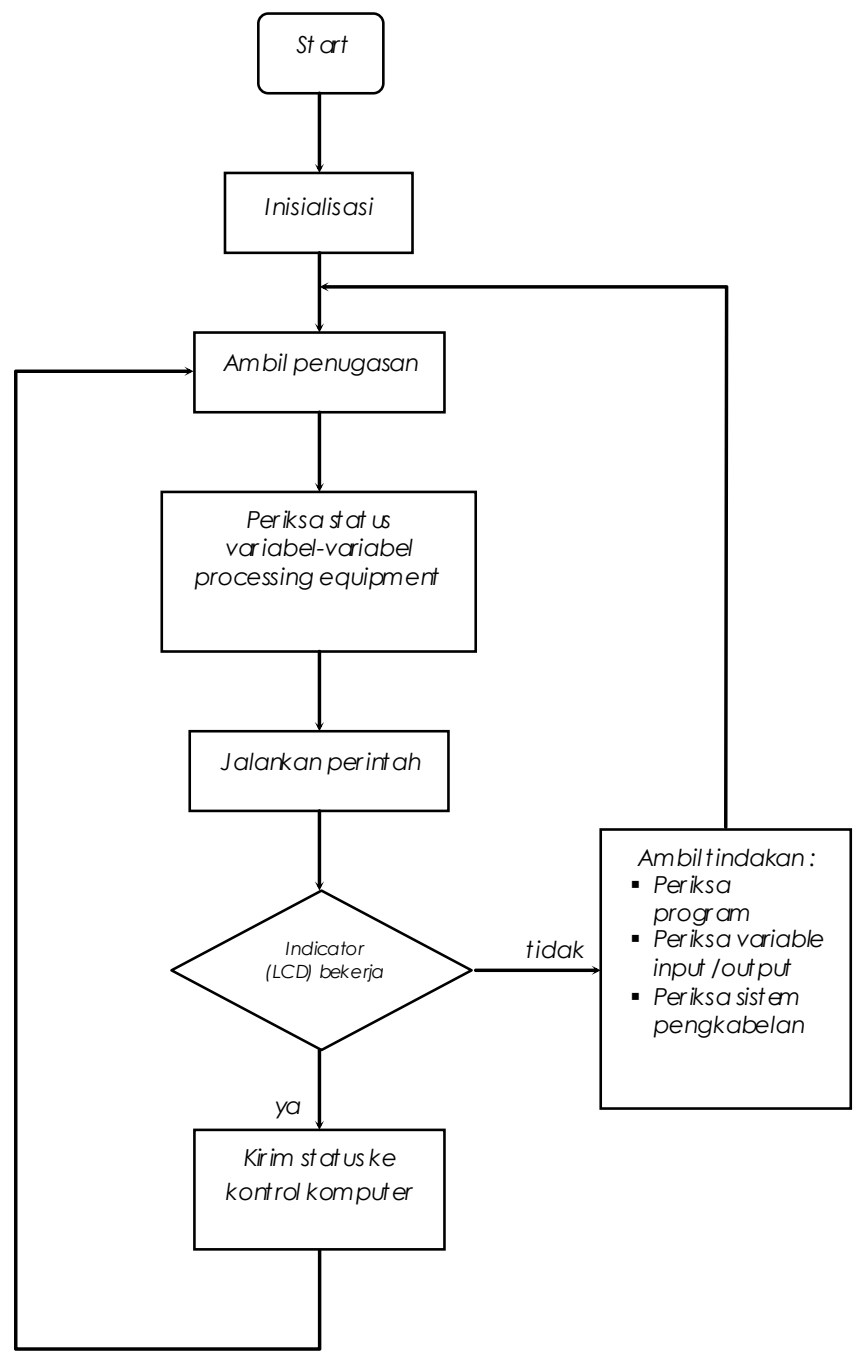

Gambar 14 Diagram alir kontrol PLC 
Fungsi-fungsi kontrol PLC, yaitu :

- Fungsi penerimaan dan penerjemahan tugas/perintah

- Fungsi pengendali komponen input/output Processing equipment

- Fungsi pengambilan keputusan pelaksanaan perintah

\section{Analisa Sistem Kontrol}

Seperti telah dijelaskan pada bab 3, bahwa analisa kontrol merupakan proses yang sejalan dengan proses perancangan-pembuatan.

\section{a) Sistem Kontrol Eretan Atas}

Berikut ini adalah proses perhitungan Mekanika Daya Sekerup leadscrew berdasarkan persamaanpersamaan yang digunakan pada perhitungan analisa sistem kontrol bab 3 .

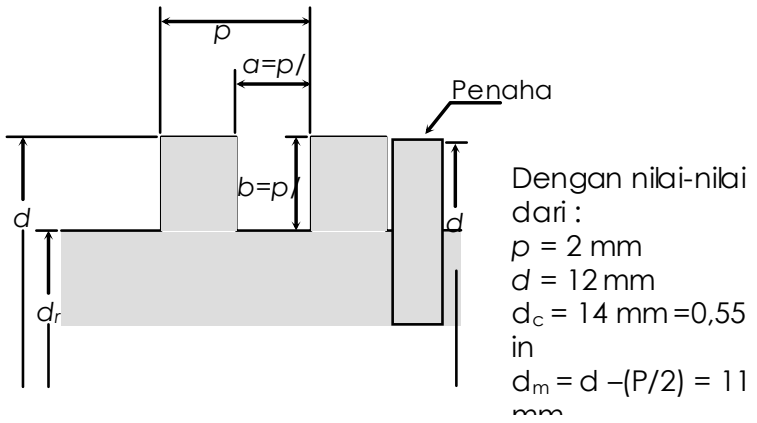

Gambar 15. Mekanika Daya Sekerup leadscrew Eretan Atas

Kecepatan jarak-maju eretan tergantung dari jenis ulir leadscrew yang digunakan, pada penelitian ini, standar ulir yang dipakai adalah ulir / sekrup daya. Dengan mengacu pada mekanika ulir / sekrup daya (lihat gambar 15), maka jarak-maju/mundur eretan, gaya dan torsi dari sistem mekanik penggerak eretan atas adalah :

jarak-maju leadscrew per ulir, yaitu :

$l=n \cdot p=2 \times 2=4 \mathrm{~mm}$, denganfaktor keamanan $(n)$

y angmerupakanharga praktris AGMA dimana $n \geq 2$

$\tan \lambda=\frac{l}{\pi d_{m}}$, adalah sudut maju ulir, yaitu :

$$
\tan \lambda=\frac{2}{\pi .11}
$$$$
\tan \lambda=0,058
$$

$$
\lambda=\tan ^{-1} 0,058
$$$$
\lambda=3,31^{\circ}
$$

$T=\frac{63000 H}{n}$, daya putar motor penggerak adalah :

$$
T=\frac{63000 \times 1}{30}=2100 \mathrm{lb} \cdot \mathrm{in}
$$

$\mu \geq \tan \lambda$, adalah kondisi untuk mengunci sendiri (self-locking). Dimana koefesien gesek bantalan penahan adalah :

$\mu=\frac{l}{\pi d_{c}}=\frac{4}{3,14 \times 14}=0,09$, maka kondisi mengunci sendiri yaitu : 0,09 $\geq 0,058$, sehingga dapat dikatakan leadscrew eretan dapat melakukan self-locking.

$T=\frac{F \cdot \mu \cdot d_{C}}{2}$, dengan asumsi gaya pada eretan adalah sebesar $1500 \mathrm{~N}$, dan beban terpusat pada bantalan penahan, maka daya putar untuk menaikkan beban/memutar leadscrew adalah sebesar :

$T=\frac{1500 x 0,058 \times 0,55}{2}$

$T=47,85 \mathrm{lb}$.in

Persamaan 3.9: $\quad \frac{F V}{33000}=\frac{T n}{63000}, \quad$ kecepatan jarak-maju / mundur eretan atas adalah :

$V=\frac{33000 \times 47,85 \times 30}{63000 \times 1500}$

$V=0,5 \mathrm{fpm}=0,1525 \mathrm{~m} / \mathrm{min}=2,54 \mathrm{~mm} / \mathrm{det}$

\section{b) Sistem Kontrol Eretan Bawah}

Berdasarkan perancangan dan proses pembuatan pada sistem kontrol eretan bawah, dengan menggunakan persamaan 3.1 maka putaran pada roda yang digerakkan (third shaft $-n_{F}$ ) menjadi :

$n_{F B}=40 \frac{42}{70}$, beban yang dipindahka $n$ ( transmittel load) roda gigi $A$ ke roda gigi $B$ :

$n_{F B}=24 \mathrm{rpm}$

$n_{F C}=24 \frac{30}{98}$, beban yang dipindahka $n$ ( transmittel load ) roda gigi $A$ ke roda gigi $B$ :

$n_{F C}=7,3 \quad \mathrm{rpm} \approx 8 \mathrm{rpm}$

Sedangkan proses perhitungan Mekanika Daya leadscrew Eretan tersebut adalah sebagai berikut.

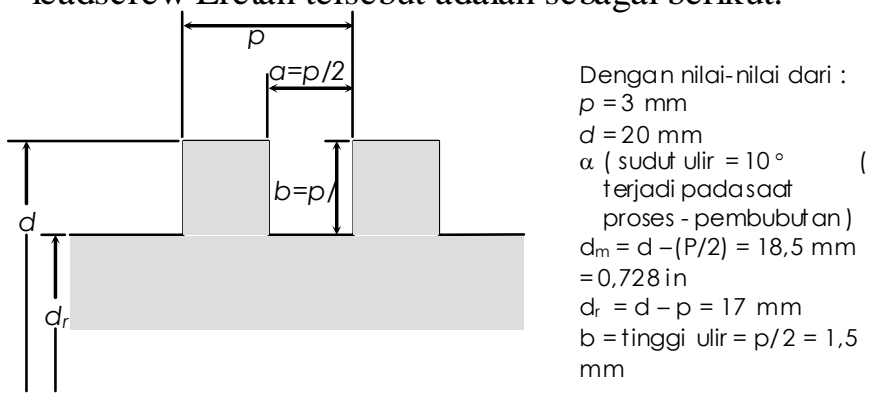

Gambar 16. Mekanika Daya Sekerup leadscrew Eretan Bawah 


\subsubsection{Pengendalian Waktu Proses}

Seperti telah dijelaskan, penentuan batas toleransi digunakan sebagai suatu nilai standar waktu jarak-maju/mundur kedua eretan. Dengan menggunakan persamaan 3.10, sehingga dihasilkan nilai kecukupan data untuk eretan atas $\mathrm{N}^{\prime}=89<\mathrm{N}$ $=35$ sedangkan $\mathrm{N}^{\prime}=2.83<40$ untuk eretan bawah.

Beberapa alasan digunakannya persamaan matematis batas toleransi adalah berdasarkan uji kecukupan data $\mathrm{N} \geq 30$, sebaran data-nya berdistribusi normal. Sedangkan rata-rata $\mu$ dan simpangan baku $\sigma$ tidak diketahui. Sehingga, untuk menaksir batas toleransi, mengganti nilai $\mu$ dan $\sigma$ masing-masing dengan taksiran sampel $x$ dan $s$, sedangkan nilai k diperoleh dari tabel.

Tabel 2. Hasil Peritungan $\mathrm{x}$ dan s pada gerak maju eretan atas tanpa speleng

\begin{tabular}{|c|c|c|c|}
\hline & Mean & Std & N \\
\hline Maju & 2.2743 & 2241 & 35 \\
Speleng & 1.210 & 2499 & 35 \\
\hline
\end{tabular}

Tabel 3. Hasil Peritungan $\mathrm{x}$ dan s pada gerak mundur eretan atas dengan speleng

\begin{tabular}{|c|c|c|c|}
\hline & Mean & Std & $\mathrm{N}$ \\
\hline Maju & 12.107 & 24.995 & 35 \\
Speleng & 1.063 & 24.729 & 35 \\
\hline
\end{tabular}

Tabel 4. Hasil Peritungan $\mathrm{x}$ dan s pada gerakan eretan bawah

\begin{tabular}{|c|c|c|c|}
\hline & Mean & Std & N \\
\hline $\begin{array}{c}\text { Maju / } \\
\text { Mundur }\end{array}$ & 1.1200 & 07752 & 35 \\
\hline
\end{tabular}

Dengan nilai $\gamma=0,99$ dan $1-\alpha=0.95$, sehingga Batas Toleransi jarak-maju/mundur kedua eretan dapat ditentukan, yaitu :

Jarak maju Eretan Atas tanpa speleng, yaitu :

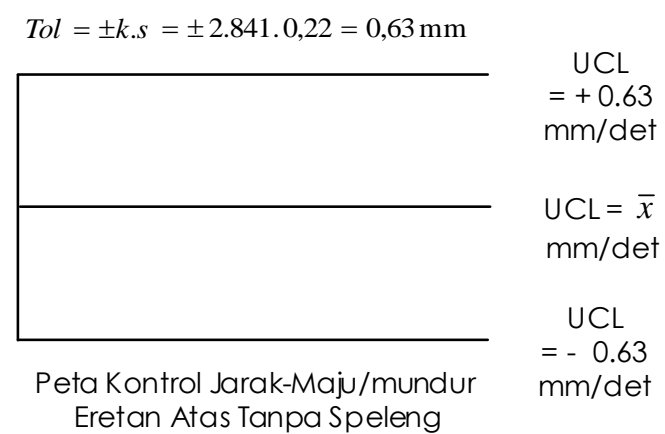

- Jarak mundur Eretan Atas dengan speleng, yaitu :

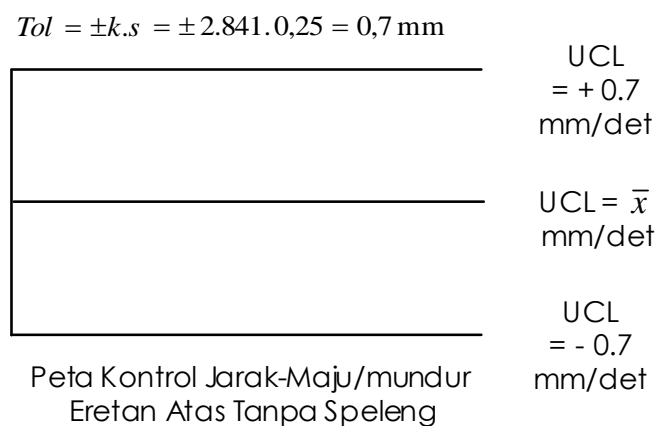

- Jarak maju/mundur eretan bawah, yaitu :

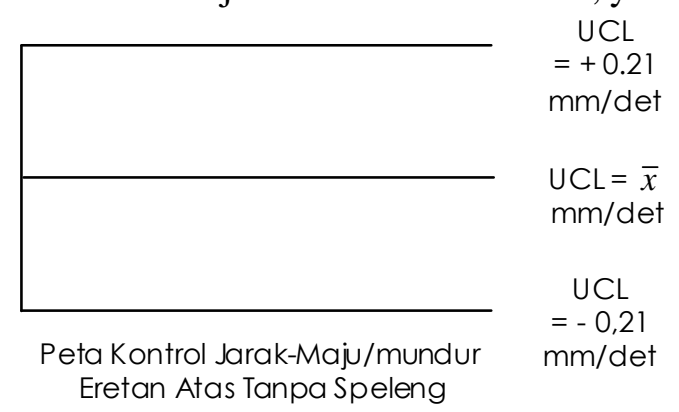

Berdasarkan teori batas tengah maka nilai ratarata gerak maju pada tabel $4.3 \mathrm{a}, 4.3 \mathrm{~b}, 4.3 \mathrm{c}$ digunakan sebagai waktu standar operasi dalam mengoperasikan mesin dengan menggunakan PLC pada fungsi-fungsi tertentu didalamnya, seperti fungsi timer. Sedangkan batas toleransi juga digunakan sebagai besarnya penyimpangan yang dapat dilakukan oleh masing-masing motor penggerak pada setiap proses operasi pembubutannya.

\subsubsection{Pengujian Ketelitian Ge rakan Sistem Kontrol Otomatis}

\section{a) Ketepatan}

Ketepatan adalah perbedaan antara posisi yang diinginkan dengan yang dicapai. Hasil yang dicapai adalah :

1. Hipotesis bahwa sampel-sampel untuk kedua arah gerak eretan atas berasal dari populasi yang sama diterima, sehingga untuk seluruh daerah kerja gerak eretan tersebut, distribusi ketepatannya normal.

2. Hipotesis bahwa sampel-sampel arah gerak eretan bawah berasal dari populasi yang sama diterima, sehingga daerah kerja ketepatan gerakan eretan berdistribusi normal.

Dengan demikian, berdasarkan teori batas tengah, distribusi ketepatan gerakan cenderung atau mendekati normal. 
b) Mampu Ulang

1. Hipotes is bahwa sampel-sampel untuk gerak eretan atas berasal dari populasi yang sama diterima, sehingga untuk seluruh daerah kerja gerak eretan tersebut, distribusi mampu ulangnya normal.

2. Hipotes is bahwa sampe-sampel arah gerak eretan bawah berasal dari populasi yang sama diterima, sehingga daerah kerja mampu ulang gerakan eretan berdistribusi normal.

Dengan proses yang sama pada perhitungan ketepatan gerakan, kita dapat menentukan bahwa distribusi mampu ulangnya cenderung atau mendekati normal. Sehingga, teori batas tengah-pun terbukti seperti halnya pada perhitungan ketepatan gerakan.

\subsubsection{Pengukuran Perbandingan Performansi Kedua Mesin}

Pengukuran performansi dilakukan untuk menentukan perbandingan performansi diantara keduanya. Pengukuran performansi dalam hal ini adalah melalui perbandingan perhitungan waktu proses dengan metode statistika uji dua rata-rata.

Tabel 5. Data Mentah Pengukuran Performansi danPerolehan $\mathrm{T}_{\text {hitung }}$ serta $\mathrm{T}_{\text {tabel }}$

\begin{tabular}{|c|c|c|c|c|}
\hline \multirow{2}{*}{\multicolumn{2}{|c|}{ No Sampel }} & \multirow{2}{*}{$\begin{array}{c}\text { Waktu Proses } \\
\text { Operasi ( t ) }\end{array}$} & \multicolumn{2}{|c|}{$\begin{array}{c}\varnothing \text { yang Dihasilkan } \\
(\mathrm{mm})\end{array}$} \\
\hline & & & Sisi II & Sisi I \\
\hline \multirow{2}{*}{ I } & $\begin{array}{l}\text { Otomati } \\
\mathrm{s}\end{array}$ & 5.51 & 18.4 & 15.1 \\
\hline & Manual & 9.03 & 18 & 15.3 \\
\hline \multirow{2}{*}{ II } & OOtomati & 5.25 & 17.85 & 14.76 \\
\hline & Manual- & 9.16 & 18.7 & 16.75 \\
\hline \multirow{2}{*}{ III } & $\begin{array}{l}\text { Otomati } \\
\text { s }\end{array}$ & 5.47 & 18.1 & 15.4 \\
\hline & Manual & 9.18 & 18.2 & 16.5 \\
\hline & & & $\mathrm{T}_{\text {hitung }}=$ & -39.5 \\
\hline & & & $\mathrm{T}_{\text {tabel }}=$ & 2.132 \\
\hline & & & $\begin{array}{r}\mathrm{N}^{6} \\
\text { Otomatis } \\
=\end{array}$ & 0.85 \\
\hline & & & $\begin{array}{c}\mathrm{N}^{6} \\
\text { Konvensio } \\
\text { nal }=\end{array}$ & 0.29 \\
\hline
\end{tabular}

Diperoleh $\mathrm{T}_{\text {hitung }}$ sebesar $-39,5$ sedangkan $\mathrm{T}_{\text {tabel }}<$ -2.132 dan $\mathrm{T}_{\text {tabel }}<2$ 2.132. Berdasarkan proses perhitungan yang telah dilakukan maka kita dapat menentukan bahwa $H o$ ditolak, artinya, performansi kedua mesin tidak sama. Sedangkan nilai $\mathrm{T}_{\text {hitung }}$ jatuh di wilayah kritis bagian kiri, maka kita dapat menyimpulkan bahwa performansi mesin otomatis lebih baik dari pada mesin konvensional.

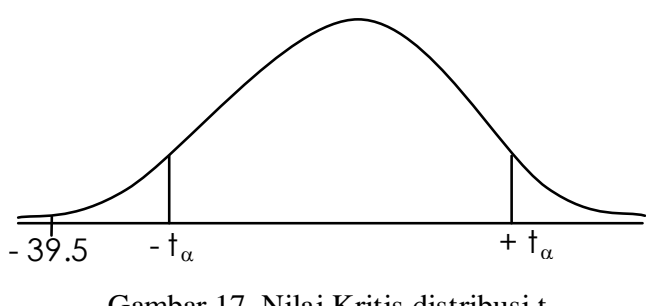

Sebagai langkah terakhir dari proses pengukuran performansi adalah pengukuran variansi dari performansi itu sendiri. Maka $\mathrm{F}_{\text {hitung }}=2,95$ dimana $<$ $\mathrm{F}_{\alpha=0,05}=9,28$ Sehingga kita dapat menentukan bahwa variansi kekuatan kedua mesin adalah sama (Terima Ho).

\section{Kesimpulan}

Kesimpulan dari hasil penelitian, yaitu :

1. Sistem kontrol otomatis dengan menggunakan PLC dapat diaplikasikan pada mesin bubut BV20 konvensional.

2. Penerapan drives dengan menggunakan motor drives electric hasil perancangan untuk eretan baik eretan atas maupun eretan bawah saat ini tidak efektif, karena memiliki karakteristik tersendiri, diantaranya backlash pada sistem roda gigi motor.

3. Langkah-langkah proses pengoperasian mesin bubut otomatis BV-20, yaitu :

1. Identifikasi komponen input/output PLC,

2. Pembuatan rangkaian pengendali komponen-komponen diatas, terdiri dari :

a. Rangkaian tetap/Diagram Daya ( mesin ),

Telah terpasang pada mesin - Electronic Control Box.

b. Rangkaian pengendali

c. Rangkaian utama

3. Instalasi

4. Berdasarkan proses pengendalian waktu proses kecepatan jarak maju/mundur yang digunakan dalam proses operasi mesin BV-20 semi otomatis, yaitu :

Sistem kontrol eretan atas :

- Dengan speleng :

Kecepatan jarak-maju/mundur $=2,27$ $\mathrm{mm} /$ det, dengan batas toleransi $= \pm \mathbf{0 , 7}$ $\mathrm{mm} / \mathrm{det}$

- Tanpa speleng :

Kecepatan jarak-maju/mundur $=1,06$ $\mathrm{mm} /$ det, dengan batas toleransi $= \pm \mathbf{0 , 6 3}$ $\mathrm{mm} / \mathrm{det}$

Sistem kontrol eretan bawah, yaitu : 
Kecepatan jarak-maju/mundur $=1,12$ $\mathrm{mm} /$ det, dengan batas toleransi $= \pm \mathbf{0 , 2 1}$ $\mathrm{mm} / \mathrm{det}$

Untuk penelitian lanjutan, penulis memberikan saran sebagai dasar dalam penelitian lanjutan, yaitu :

1. Proses perancangan dan pembuatan sebaiknya dilakukan secara bertahap. Pertama kali dirancang sistem secara keseluruhan dengan rinci, kemudian proses perancangan dan pembuatan dilakukan secara brtahap modul permodul. Alasannya, karena proses prancanganpembuatan pasti akan bersifat iteratif, selalu akan terjadi perubahan rancangan.

2. Penelitian lebih lanjut dalam menggunakan motor penggerak khusus, misalnya dengan menggunakan motor servo dan atau pengendalian mekanika gerak otomatis dengan sistem pneumatic motor control untuk mendapatkan ketelitian ukuran dan kepresisian hasil pembubutan.

3. Sampai tahapan yang telah dilakukan, sistem kontrol otomatis belum dapat dioperasikan secara optimal seperti yang diinginkan, sangat diharapkan bahwa apa yang telah dikerjakan disini dilanjutkan ke pengoperasian sistem kontrol pada proses operasi pembuatan produk secara nyata ( Real Time Control ) dengan pencapaian ketelitian ukuran dan kepresisian hasil pembubutan pada tingkat mikro $(0,00 \mathrm{~mm}$ ) .

\section{DAFTAR PUSTAKA}

1. Groover, P. Mickell. " Automation, Product Planning and Inventory Control “, Mc. Graw Hill, 1987.

2. Pesson, W. David. " Industrial Automation ", John Willey \& Sons, Inc, 1989.

3. Webb, W. John \& Reis, A. Ronald. Programmable Logic Control “. Copyright (C) 1999, 1995 by Prentice Hall, Inc.

4. Tien-Chien Chang, Richard A. Wysk, HsuPin Wang.

" Computer Aided

Manufacturing “. Copyright (C) 1998, 1991 by Prentice Hall, Inc.

5. Asfahl, C. Ray. " Robot and Manufacturing Automation ". Copyight (c) 1985, 1992 by John Willey \& Sons, Inc, 1938.

6. Monden, Yasuhiro. " Sistem Produksi Toyota “. Copyright (C) 1993 Yasuhiro Monden, 1993.
7. Suzaki, Kiyoshi. “ Tantangan Industri Manufaktur “. Copyright (C) by Kiyoshi Suzaki, 1987.

8. Sutalaksana, Z. Itfikar. " Tata Cara Kerja ".

9. Shigley, E Joseph \& Mitchell, D.Larry. Perencanaan Teknik Mesin Jilid 1 dan 2 “. Pe nerbit Erlangga - Jakarta, 1983.

10. P. Van. Harten. “Instalasi arus Kuat 3 “. Penerbit CV. Trimitra Mandiri, Jakarta, 1983.

11. Walpole E. Ronald \& MyersH. Raymond. “ Ilmu Peluang dan Statistik untuk Insinyur dan Ilmuwan ", Penerbit ITB Bandung, 1986.

12. Ulrich T. Karl \& Eppinger D. Steven.

Perancangan dan Pengembangan Produk “, Penerbit Salemba Teknika, 2001.

13. Cohen P. William. "Quality Function Deployment “, ... “ Jurnal Seminar Tugas Akhir “, Universitas Jenderal Ahmad Yani-Bandung, 2000.

14. Djodikusumo Indra. " Mekatronika 1 \& 2 ". Lab. Otomasi \& Robot Jur. Teknik Mesin FTI-ITB Bandung, 1996.

15. “Modul Pelatihan PLC ", Balai Latihan Kerja - Bandung, tahun 2002.

16. " Perancangan, Pembuatan dan Pengoperasian Prototipe AGV “. Chandra Irawan, TA-ITB, Bandung, 1995.

17. " Analisis Perbandingan Manual dan Otomasi dengan Coordinat Measuring Machine ( CMC )...". Deded Suhendar, TA-UNJANI, Bandung, 1999.

18. “Draft Kuliah Proses Manufaktur 1 ".Ir. H. Toto Saputra, MM. TI - UNJANI Bandung. 